\title{
The Increased Expressions of Type IV Collagen in Cochlear Fibroblasts of Diabetic Rat Models Caused by Curcumin Therapy
}

\author{
Tengku Siti Hajar Haryuna ${ }^{1 *}$, Farhat Farhat ${ }^{1}$, Faathir Agung Ainul Taufika ${ }^{1}$, Juliandi Harahap ${ }^{2}$, Lidya Imelda Laksmi ${ }^{3}$, \\ Wayan Suardana ${ }^{4}$ \\ ${ }^{1}$ Department of Otorhinolaryngology, Faculty of Medicine, Universitas Sumatera Utara, Medan 20155, Indonesia. \\ ${ }^{2}$ Department of Community Medicine, Faculty of Medicine, Universitas Sumatera Utara, Medan 20155, Indonesia. \\ ${ }^{3}$ Department of Anatomical Pathology, Faculty of Medicine, Universitas Sumatera Utara, Medan 20155, Indonesia. \\ ${ }^{4}$ Department of Otorhinolaryngology, Faculty of Medicine, Universitas Udayana, Denpasar 80113, Indonesia.
}

\begin{tabular}{|c|c|}
\hline ARTICLE INFO & ABSTRACT \\
\hline $\begin{array}{l}\text { Article history: } \\
\text { Received on: } 10 / 03 / 2017 \\
\text { Accepted on: } 30 / 04 / 2017 \\
\text { Available online: } 30 / 06 / 2017\end{array}$ & $\begin{array}{l}\text { Damage to fibroblasts within the cochlear lateral wall is suggested as one of the causes of hearing loss in } \\
\text { patients with diabetes mellitus. The aim of this study was to prove curcumin as a safe and effective substance to } \\
\text { treat the cochlear fibroblasts damage measured by the expressions of type IV collagen. Twenty-four Rattus } \\
\text { norvegicus were randomly divided into } 6 \text { groups }(n=4) \text {. Group I: the control group; group II: the diabetic group; }\end{array}$ \\
\hline $\begin{array}{l}\text { Key words: } \\
\text { Diabetes mellitus, curcumin, } \\
\text { type IV collagen, fibroblast, } \\
\text { cochlea. }\end{array}$ & $\begin{array}{l}\text { group V and VI: the diabetic groups received curcumin therapy } 200 \text { and } 400 \mathrm{mg} / \mathrm{kgBW} / \text { day from day } 3-10 \text {. } \\
\text { Curcumin }[16.62 \pm 0.14] \% \text { w/w compared to Standard was administered orally, derived from Curcuma longa } \\
\text { Linnaeus (turmeric). All samples were immunohistochemistrically examined for the expressions of type IV } \\
\text { collagen in cochlear fibroblasts. Statistically significant differences were found for the expressions of type IV } \\
\text { collagen (p }<0.05 \text { ) between group I and II, group II and V, and group II and VI. Curcumin proved to be } \\
\text { potentially effective in the treatment of damage to cochlear fibroblasts regarding the increased expression of } \\
\text { type IV collagen in diabetic rat models. }\end{array}$ \\
\hline
\end{tabular}

\section{INTRODUCTION}

Diabetes Mellitus (DM) is a metabolic disorder characterized by high levels of blood glucose due to defects in insulin secretion and/or insulin action (Azmi et al., 2015). Chronic hyperglycemia can cause some complications, including cardiac and renal dysfunction and difficult-to-treat infection (Guo et al., 2015). The association between DM and sensorineural hearing loss (SNHL) has been investigated for more than a century and most authors have the same opinion about SNHL inflicted by DM (Fukushima et al., 2005). DM is often accompanied by SNHL, which may affect both hearing sensitivity and cognitive function (Park et al, 2012).

\footnotetext{
* Corresponding Author

Tengku Siti Hajar Haryuna, Department of Otorhinolaryngology, Faculty of Medicine, Universitas Sumatera Utara, Medan 20155, Indonesia.Email: tengkusitihajarharyuna@gmail.com
}

The relationship between DM and hearing impairment of maternal inheritance accounts for $1.5 \%$ of all cases of DM in the Netherland and Japan (Malucelli et al., 2012). A histopathological study in temporal bones from diabetic animal models showed thickening of the basilar membrane capillaries, loss of inner and outer hair cells, atrophy of the spiral ganglion cells, swelling of intermediate cells and atrophy of marginal cells in stria vascularis (Fukushima et al., 2005). In addition to sensory cells, nonsensory cells are also pivotal in receiving sound signals. The fibrocytes within cochlear lateral wall are nonsensory cells possessing important role in ion homeostasis and endocochlear potential maintenance in the inner ear. The degeneration of fibrocytes within cochlear lateral wall may lead to hearing loss due to the reduction in endocochlear (Mizutari, 2014). Human fibroblasts normally produce type IV collagen (Rodemann and Rennekampff, 2011). Some studies about DM demonstrated type IV collagen degradation due to the increased matrix metalloproteinase-9 (MMP-9) expressions and plasminogen activator (PA)/plasmin/PA 
inhibitor (PAI) system also plays a role in extracellular matrix (ECM) degradation (Ban and Twigg, 2008). For years, many researchers have made efforts to use natural compounds plantderived as potential therapeutic agents for a variety of diseases in humans. Curcumin, a yellow pigment extracted from the rhizomes of Curcuma longa Linnaeus, is a major component of turmeric originated from Asia and commonly used as a spice and foodcoloring agent. India and China use curcumin as a traditional medicine consumed concurrently with food and potential to treat various human diseases (Trujilo et al., 2013). Curcumin has been discovered to possess anti-inflammatory, antioxidant, anti-tumor, antibacterial, antiviral and antifungal properties, thereby having a potential against various diseases including diabetes, allergies, asthma, neurodegenerative diseases, cancer, arthritis, atherosclerosis, and other chronic diseases (Gandhi et al., 2011). Previous study reported that curcumin is considered to be pharmacologically safe and effective for the prevention and treatment of the noise-exposed damage to fibroblasts within the cochlear supporting tissues and lateral wall (Haryuna et al., 2016).

Other study reported that curcumin enhanced collagen synthesis at the wound tissues (Panchatcharam et al., 2006). In addition, curcumin also has been shown to interrupt numerous cell signaling pathways, including cell cycle, proliferation, survival, invasion, angiogenesis, metastasis and inflammation (Anand et al., 2008). The role of curcumin to repair the damage to fibroblasts within cochlear lateral wall caused by DM through the molecular mechanisms of type IV collagen expressions has not been studied yet and serves as the focus on this study. This study was also carried out to compare the differences of type IV collagen expressions in the fibroblasts within cochlear lateral wall of Wistar rats (Rattus norvegicus) following the administration of 200 $\mathrm{mg} / \mathrm{kgBW} /$ day curcumin and $400 \mathrm{mg} / \mathrm{kgBW} /$ day curcumin, both for 3 days and 8 days.

\section{MATERIALS AND METHODS}

\section{Experimental treatments in animal models}

We obtained the approval from the Health Research Ethical Committee of Faculty of Medicine, Universitas Sumatera Utara (No.433/KOMET/FKUSU/2015). This study was an experimental study on Wistar rats (Rattus norvegicus). The rats were males, aged 2 - 3 months, weight $200-250 \mathrm{mg}$ and declared normally health by the veterinary consultant. This study was held in the Biochemisty Laboratory, Faculty of Medicine, Universitas Airlangga (Surabaya, Indonesia). This study used curcumin extracted from Curcuma longa Linnaeus (turmeric). Curcumin content levels of $[16.62 \pm 0.14] \%$ w/w was compared with Standard using thin-layer chromatography and densitometry. Curcumin was suspensed and administered to the rats using nasogastric tube.

This study used 24 rats (randomized post-test only control group design) divided into 6 groups, 4 rats in each group. Group I is the control group, rats were administered with intraperitoneal citrate buffer on the first day, followed by $0.5 \%$
Carboxy Methyl Cellulose (CMC) orally on the third to fifth day. Hyperglicemia in groups II to VI was achieved with streptozotocin injection (Streptozotocin, Sigma-Aldrich) $60 \mathrm{mg} / \mathrm{kg}$ on the first day. Diabetes is confirmed if the glucose concentration is $>200$ $\mathrm{mg} / \mathrm{dL}$ and verified 48 hours after streptozotocin administration (Wongeakin et al., 2009). Diabetes was assessed by collecting the venous blood from the tail of rat using blood glucose test strips (Gluko DR ${ }^{\circledR}$ Bio Sensor Allmedicus). Rats were given 200 $\mathrm{mg} / \mathrm{kgBW} /$ day curcumin orally in group III and $\mathrm{V}$ from the third day and $400 \mathrm{mg} / \mathrm{kgBW} /$ day orally in group IV and VI from the third day.

Termination were carried out on the fifth day for group I to IV, while group V and VI were terminated on the tenth day. Termination were carried out using ether inhalation. Termination was followed by temporal bone necropsy. Tissue were fixated and inserted into paraffin block. Paraffin blocks were sliced with a $4 \mu \mathrm{m}$ thickness and then placed in the object glass for staining process.

\section{Immunohistochemical assay}

Hematoxylin and eosin (HE) staining was used to determine the cochlea. After the cochlea was visibly confirmed, we performed immunohistochemistry staining with primary antibody (Polyclonal Anti-COL4A2) to asses the expressions of type IV collagen on the fibroblasts of the cochlear lateral wall. Type IV collagen expression were furtherly assessed using microscope (Olympus XC 10) under 40x magnification, marked by brown colors in the cytoplasm of fibroblasts within the cochlear lateral wall.

\section{Statistical analysis}

All data were analyzed using SPSS version 22 (SPSS Inc., NY, USA). Before running the analysis, we performed normality test. T-Test analysis is plotted for normally distributed data, while Mann-Whitney analysis is plotted for abnormally distributed data. A $p<0.05$ indicates statistically significant.

\section{RESULTS}

\section{The effect of curcumin on type IV collagen immunohistochemistrically}

The cochlear tissues of rats were immunohistochemistrically examined using a microscope in order to assess the expressions of type IV collagen (Fig. 1).

The expressions of type IV collagen after being evaluated with immunohistochemistry method were found to be decreased in DM groups that did not receive curcumin (Fig. 2B) compared to other groups. The expressions of type IV collagen were found to be greater in DM groups receiving curcumin, marked by more densely brown-colored fibroblasts compared to DM groups that did not receive curcumin. (Fig. 2C, 2D, 2E and 2F). 


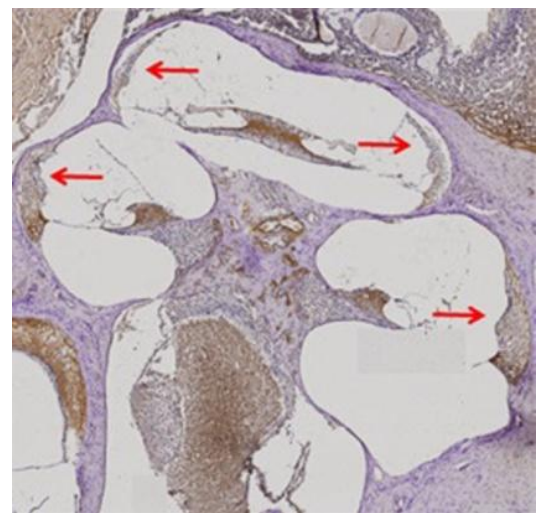

Fig. 1: The immunohistochemistry status of rats' cochlear tissues examined with a microscope with a $4 x$ magnification. Red arrows shows the cochlear lateral wall.

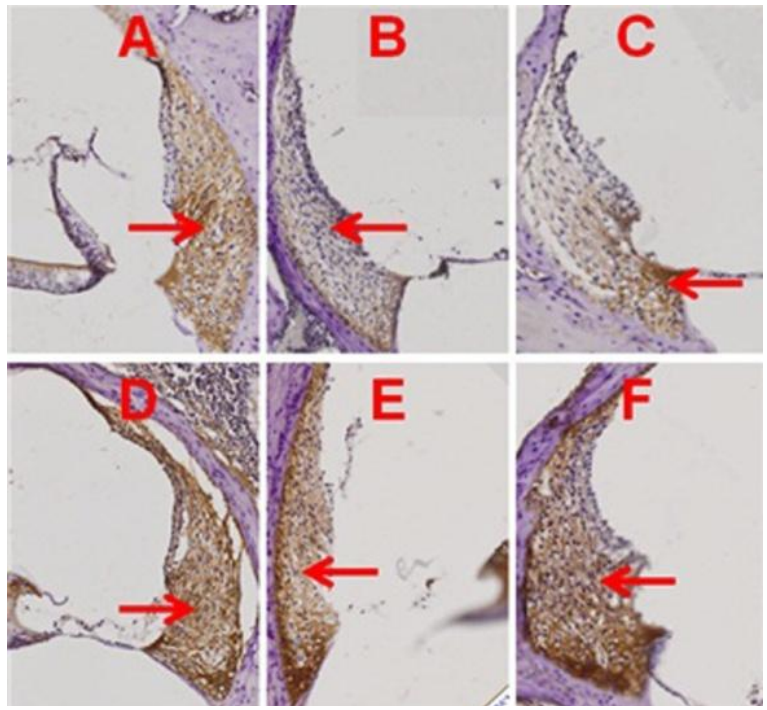

Fig. 2: Red arrows shows the immunohistochemistry of type IV collagen in fibroblasts of rats' cochlea from each group (40x zoom) with a brown-coloured expression on the cytoplasma (A) Group I; (B) Group II; (C) Group III; (D) Group IV; (E) Group V and (F) Group VI.

\section{Statistical analysis}

The analysis above (table 1) showed significant differences between group I and II, group II and V, and group II and VI.

Table 1: Analysis test results of type IV collagen expressions.

\begin{tabular}{cc}
\hline Groups & $\boldsymbol{P}$ value \\
\hline Group I (CON) and group II (DM) & $0.011^{*}$ \\
Group II (DM) and group III (DM + C200 3 days) & 0.155 \\
Group II (DM) and group IV (DM + C400 3 days) & 0.089 \\
Group II (DM) and group V (DM + C200 8 days) & $0.010^{*}$ \\
Group II (DM) and group VI (DM + C400 8 days) & $0.015^{*}$ \\
\hline
\end{tabular}

CON, control; DM, diabetes; C200, curcumin (200 mg/kgBW/day, p.o.); C400, curcumin $(400 \mathrm{mg} / \mathrm{kgBW} /$ day, p.o.). *Denotes statistically significant $(p<0.05)$.

\section{The histogram of mean values of type IV collagen expressions in each group}

The mean values of type IV collagen expressions were found to be decreased in group II (DM group that did not receive curcumin) compared to group I (control) and increased in DM groups receiving curcumin (group III, IV, V and VI) compared to group II (DM group that did not receive curcumin) (Fig. 3).

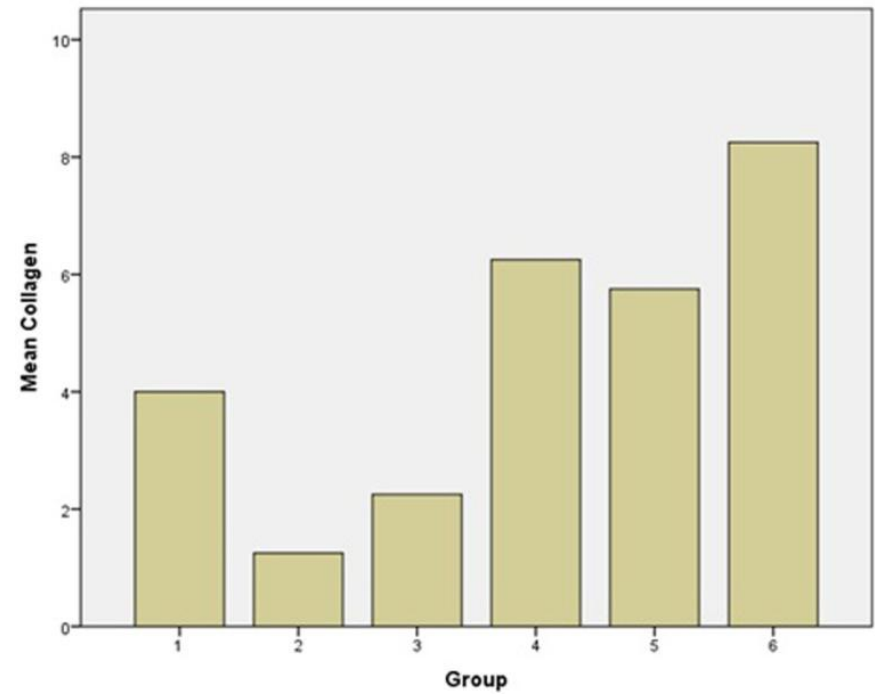

Fig. 3: Mean Type IV Collagen Expression of Each Group.

\section{DISCUSSION}

Type IV collagen is found in the basilar membrane, spiral ligament, and stria vascularis, but how the damage to type IV collagen may lead to sensorineural hearing loss has not yet been elucidated (Keats and Berlin, 1999). According to the result of immunohistochemistry assay performed in our study (Fig. 2), the expressions of type IV collagen detected in the cytoplasm of fibroblasts within the cochlear lateral wall of the diabetic group without curcumin administration (group II) demonstrated lower density seen in the brown color compared to the control group (group I). This result proved the damage to fibroblasts within the cochlear lateral wall caused by DM viewed from the decrease in type IV collagen expressions. The damage to type IV collagen due to DM may occur in several ways as reported in the previous study which there is a plasminogen-plasmin system that degrades ECM proteins in DM, including type IV collagen. Plasmin is one of the primary catalytic activators of latent metalloproteinases (collagenase) that takes responsibility for the proteolysis of ECM proteins (Kwaan, 1992). DM is also associated with dysregulation in the circulating MMP/tissue inhibitors of metalloproteinase (TIMP) system, inflicting an increased in MMP-9 and TIMP-1, leading to type IV collagen degradation in type 1 and/or type 2 DM, even if the complications have not yet occurred (Ban and Twigg, 2008). Both MMPs and plasmin have also been implicated in the abnormal degradation ECM in DM (McLennan et al., 2000). The authors believe that, in our study, all the pathways mentioned above play the role in the damage to type IV collagen on fibroblasts within the cochlear lateral wall caused by DM. The result of immunohistochemistry assay performed in our study also demonstrated the increase in type IV collagen expression detected in the cytoplasm of fibroblasts within the cochlear lateral wall of 
DM groups with curcumin administration (group III, IV, V and VI) which demonstrated higher density seen in the brown color compared to DM group without curcumin administration (group II).

The influence of curcumin on the increase of type IV collagen reported in our study is supported by previous study on DM that has found the ability of curcumin in inducing the transforming growth factor- $\beta 1$ (TGF- $\beta 1$ ) to stimulate the expressions of collagen on fibroblasts (Maheshwari et al., 2006). In addition, curcumin can also decrease the expressions of cytokine/inflammatory enzymes, such as MMP-9, leading to type IV collagen degradation (Kant et al., 2014). The roles of curcumin explained above emphasize its benefit in treating the damage to type IV collagen, that are consistent with the results of our study on fibroblasts within the cochlear lateral wall viewed from the expressions of type IV collagen. Endocochlear potential is essential in hearing physiology (Mizutari, 2014). Sound transduction is also necessary in hearing physiology, which audible sound is delivered to nerve impulse performed by the inner hair cells when the basilar membrane is moved by the sound wave (Alberti, 2001). The tension of basilar membrane is also regulated by spiral ligament attached to it, depending on the fibroblasts in spiral ligament containing of contractile proteins. Regarding that matter, collagen plays a pivotal role to regulate the movement and elasticity of basilar membrane in the process of sound transduction (Raphael and Altschuler, 2003). Based on one of the benefits of collagen in hearing transduction, our study found that the administration of curcumin increased the expressions of type IV collagen in fibroblasts within cochlear lateral wall (group III, IV, $\mathrm{V}$ and VI) compared to curcumin untreated-group (group II), indicating that curcumin is able to repair the damage to the fibroblasts of cochlear lateral wall caused by DM.

In this study, we used curcumin at dose of 200 $\mathrm{mg} / \mathrm{kgBW} /$ day in regards to previous study which reported that, in numerous studies conducted on animal models, curcumin at doses 100-200 mg/kgBW showed the favorable result as antiinflammatory therapy (Kohli et al., 2005). Previous study reported that curcumin at doses of up to $400 \mathrm{mg} / \mathrm{kgBW} /$ day for 10 days exerted antioxidant activity to inhibit $\mathrm{K} 2 \mathrm{Cr} 2 \mathrm{O} 7$ induction, indicating that curcumin acts as a nephroprotectant in rats (Molina-Jijón et al., 2011). Other study reported that the administration of curcumin at doses of up to $2000 \mathrm{mg}$ /day showed no marked side effects (Gaedake et al., 2005). According to those previous studies, the authors investigated the comparison between curcumin at doses $200 \mathrm{mg} / \mathrm{kgBW} /$ day and $400 \mathrm{mg} / \mathrm{kgBW} /$ day for 8 days since both doses were considered to be safe in rats. Due to its safe dosage, we conducted this study in a shorter span within 3 days. Our statistical analysis (table 1) showed that the administration of $200 \mathrm{mg} / \mathrm{kgBW} /$ day and $400 \mathrm{mg} / \mathrm{kgBW} / \mathrm{day}$ curcumin for 3 days increased the expressions of type IV collagen in the fibroblasts within the cochlear lateral wall of diabetic rats (groups III and IV) compared to the DM group that did not receive curcumin (group II), but the increased expressions were statistically insignificant. The significant increased expressions were found in DM groups receiving curcumin administration with a dosage of $200 \mathrm{mg} / \mathrm{kgBW} /$ day and $400 \mathrm{mg} / \mathrm{kgBW} /$ day for 8 days (groups $\mathrm{V}$ and VI). This shows that curcumin administration with a dosage of $200 \mathrm{mg} / \mathrm{kgBW} /$ day and $400 \mathrm{mg} / \mathrm{kgBW} /$ day for 8 days is better than the administration of the same dosage for 3 days in repairing damage to the fibroblasts of cochlear lateral wall caused by DM through the molecular mechanisms of type IV collagen expressions.

\section{CONCLUSION}

Curcumin is considered to be a safe and effective therapeutic agent in repairing the damage to fibroblasts in cohclear lateral wall caused by DM, which is determined through the expressions of type IV collagen. Moreover, this study thus provides more insight into the mechanism of curcumin towards the expressions of type IV collagen. This study serves as a scientific basis for the usage of curcumin in the traditional system of medicine for the management of hearing loss inflicted by DM in the future.

\section{ACKNOWLEDGMENTS}

The authors are deeply indebted to DIPA (Direktorat Penelitian Pengabdian kepada Masyarakat Universitas Sumatera Utara) Universitas Sumatera Utara 2015 (120/SP2H/PL/ Dit.Litabmas/II/2015) for the financial support; The authors also would like to thank Biochemisty Laboratory, Faculty of Medicine, Universitas Airlangga Surabaya; Anatomic Pathology Laboratory, Faculty of Medicine and Dr. Soetomo General Hospital Surabaya, for providing equipment and scientific apparatus.

Conflict of Interests: There are no conflicts of interest.

\section{REFERENCES}

Alberti PW. 2001. The anatomy and physiology of the ear and hearing. In: Goelzer B, Hansen CH, Sehrndt GA, ed. Occupational exposure to noise: evaluation, prevention and control. Bremerhaven: World Health Organization 53-62.

Anand P, Sundaram C, Jhurani S, Kunn umak kara AB, Aggarwal BB. Curcumin and cancer: An "old-age" disease with an "ageold" solution. Cancer Lett, 2008; 267:133-64.

Azmi MB, Qureshi SA, Rais S, Sultana S. Methanolic root extract of rauwolfia serpentina lowers atherogenic dyslipidemia, arteriosclerosis and glycosylation indices in type 1 diabetic mice. J App Pharm Sci, 2015; 5:61-7.

Ban CR, Twigg SM. Fibrosis in diabetes complications: pathogenic mechanisms and circulating and urinary markers. Vasc Health Risk Manag, 2008; 4:575-96.

Fukushima H, Nishiike S, Masuda K, Morita N, Fukutsuji K, Yoda S, Harada T. Impairment in the sensorineural elements of the cochlea and vasculature in diabetes mellitus: a human temporal bone study. Kawasaki Med J, 2005; 31:55-62.

Gaedake J, Noble NA, Border WA. Curcumin blocks fibrosis in anti-Thy 1 glomerulonephritis through up-regulation of heme oxygenase 1 . Kidney Int, 2005; 68:2042-9.

Gandhi P, Khan Z, Chakraverty N. Soluble curcumin: A Promising oral supplement for health management. J App Pharm Sci, 2011; 1:1-7. 
Guo Z, Jiao Y, Yi Z, Li R, Zhang Y. Increased risk of hyperglycemia associated with the use of everolimus in patients with cancer: a systematic review and meta-analysis. J Chin Pharm Sci, 2015; 24:326-35.

Haryuna TSH, Lutan R, Taufika FAA, Anggraeni R, Zubaidah TSH. Effect of Curcuma longa L. extract on the AP1 expression in rat cochlear fibroblasts under noise conditions. J Chin Pharm Sci, 2016; 25:690-4.

Kant V, Gopal A, Pathak NN, Kumar P, Tandan SK, Kumar D. Antioxidant and anti-inflammatory potential of curcumin accelerated the cutaneous wound healing in streptozotocin induced diabetic rats. Int Immunopharmacol, 2014; 20:322-30.

Keats BJB, Berlin CI. Genomics and hearing impairment. Genome Res, 1999; 9:7-16.

Kohli K, Ali J, Ansari MJ, Raheman Z. Curcumin: a natural antiinflammatory agent. Indian J Pharmacol, 2005; 37:141-7.

Kwaan HC. Changes in blood coagulation, platelet function, and plasminogen-plasmin system in diabetes. DIABETES, 1992; 41:32-5.

Maheshwari RK, Singh AK, Gaddipati J, Srimal RC. Multiple biological activities of curcumin: a short review. Life Sci, 2006; 78:20817.

Malucelli DA, Malucelli FJ, Fonseca VR, Zeigeboim B, Ribas A, de Trotta F, da Silva TP. Hearing loss prevalence in patients with diabetes mellitus type 1. Braz J Otorhinolaryngol, 2012; 78:105-15.

McLennan SV, Fisher E, Martell SY, Death AK, Williams PF, Lyons JG, Yue DK. Effects of glucose on matrix metalloproteinase and plasmin activities in mesangial cells: possible role in diabetic nephropathy. Kidney Int, 2000; 58:81-7.

Mizutari K. Spontaneous recovery of cochlear fibrocytes after severe degeneration caused by acute energy failure. Front Pharmacol, 2014; 5:1-3.

Molina-Jijón E, Tapia E, Zazueta C, Hafidi ME, ZatarainBarrón ZL, Hernández-Pando R, Medina-Campos ON, Zarco-Marquez G, Torres I, Pedraza-Chaverri J. Curcumin prevents $\mathrm{Cr}(\mathrm{VI})$-induced renal oxidant damage by a mitochondrial pathway. Free Radic Biol Med, 2011; 51:1543-57.
Panchatcharam M, Miriyala S, Gayathri VS, Suguna L. Curcumin improves wound healing by modulating collagen and decreasing reactive oxygen species. Mol Cell Biochem, 2006; 290:87-96.

Park MS, Lee HY, Kang HM, Ryu EW, Lee SK, Yeo SG. Clinical manifestations of aural fullness. Yonsei Med J, 2012; 53:985-91.

Raphael Y, Altschuler RA. Structure and innervation of the cochlea. Brain Res Bull, 2003; 60:397-422.

Rodemann HP, Rennekampff HO. 2011. Functional diversity of fibroblasts. In: Mueller MM, Fusenig NE, ed. Tumor-associated fibroblasts and their matrix. Tubingen: Springer Science+Business Media BV 23-36.

Trujilo J, Chirino YI, Molina-Jijon E, Anderica-Romero AC, Tapia E, Pedraza-Chaverri J. Renoprotective effect of the antioxidant curcumin: recent findings. Redox Biol, 2013; 1:448-56.

Wongeakin N, Sridulyakul P, Jariyapongskul A, Suksamrarn A, Patumraj S. Effects of curcumin and tetrahydrocurcumin on diabetes induced endothelial dysfunction. Afr J Biochem Res, 2009; 3:259-65.

\section{How to cite this article:}

Haryuna TSH, Farhat F, Taufika FA, Harahap J, Laksmi LI, Suardana W. The Increased Expressions of Type IV Collagen in Cochlear Fibroblasts of Diabetic Rat Models Caused by Curcumin Therapy. J App Pharm Sci, 2017; 7 (06): 197-201. 